\title{
DIAGENETIC ASPECTS OF UPPER \\ JURASSIC SANDSTONES IN THE DANISH NORTH SEA SECTOR
}

\section{Extended Abstract}

\section{Palle Rubæk Andersen}

Geological Survey of Denmark, Thoravej 8, DK-2400 Copenhagen NV, Denmark

Studies of Upper Jurassic sandstone formations, the Heno Formation and the Gert unit, in the Danish North Sea sector have revealed two diverging diagenetic trends, which appear related to sedimentary environments: 1) Distal marine sands (lower shoreface to offshore) end up as reservoirs with fair porosities but low permeabilities, 2) Marginal marine sands (beach, barrierisland complex) create reservoirs with fair to high porosities and fair to high permeabilities.

The critical diagenetic factor is that distal marine environments at late stage diagenesis suffered illitization and thus impairment of permeability, while the marginal marine environment appears non-illitized. From studies elsewhere in the North Sea, Bjørlykke et al. (1986) argue that illitized sandstones arise, when potassium-bearing silicate minerals like feldspars and micas contained in the sand decompose upon burial to temperatures above c. $110^{\circ} \mathrm{C}$ (cf. Bjørkum \& Gjelsvik 1988). Non-illitized sandstones arise if no potassium-donating minerals are present when the critical burial temperatures are reached, i.e. if the sand suffered potassium depletion due to earlier burial dissolution or replacement of the minerals. Support is provided by Lønøy et al. (1986), who reported authigenic kaolinite existing metastably under formation temperatures as high as $150^{\circ} \mathrm{C}$, the reason being the lack of potassium feldspar to act as potassium donor for the transformation of the kaolinite into illite. If sands behave roughly as closed systems during deeper burial, it thus appears that early removal of potassiumdonating minerals can in some cases delay or possibly even prohibit burial formation of illite. A factor to keep up roughly closed system behaviour may be the high overpressures created in the Upper Jurassic sands by the Upper Cretaceous chalk seal. Such overpressures may help to keep out potassium-carrying exotic fluids.

Potassium donators in sand are generally feldspars and micas. Dissolution of feldspars and replacement of micas require neutral to acid porewaters, which are undersaturated with respect to these minerals. Principal sources, as discussed by Bjørlykke et al. (1986), are: (1) meteoric water, (2) acid pore water produced by expulsion of carbon dioxide from maturing kerogen in a source rock. Flushing by meteoric water is a shallow burial incident either following soon after deposition or following uplift, the latter giving the water access to previously deeper buried rocks. Invasion by maturation-generated acid fluids will generally be an intermediate to deeper burial incident. Invasion by maturation generated fluids and invasion by meteoric water following large scale uplift, are hardly likely to be dependent on the sedimentary environment of the invaded sandbodies. Invasion by meteoric water following deposition, however, is. Meteoric water flushing of marine sands will typically occur in marginal marine environments, where an elevated groundwater table in the hinter- lands can act as a pressure head to drive the fresh water into the basin. Such invasion along North Sea sector Jurassic 
coast lines has been argued to explain feldspar dissolution in marginal marine sands and no dissolution in more distal sands (Bjørlykke et al. 1986).

If the outlined mechanism is a widespread phenomenon it clearly implies that marginal marine environments are the most optimal exploration targets in regions where potential sand reservoirs have been buried deeper than $3-4 \mathrm{~km}$.

The diagenetic alterations which occurred in the barrier island complex sandstones from the Heno Formation in the Danish well Diamant-1 (5603/32-2) illustrate some of the involved processes. The study involves oxygen, carbon and strontium stable isotopes and will be presented more comprehensively elsewhere (Andersen, in prep.) The alterations are conveniently tripartitioned (fig. 1):

Step 1, very shallow burial: Pyrite, low magnesian calcite and subordinate quartz formed. Labile minerals like feldspar and aragonitic shell debris aragonite were stable. Along with isotopic evidence $\left(\delta^{18} 0,{ }^{87} S r\right)$ ${ }^{86} \mathrm{Sr}$ ) this indicates a pore water regime of evolving marine waters.

Step 2, very shallow burial: Pore filling kaolinite, $\mathrm{Fe}$ - calcite and baryte formed along with minor quartz, dolomite, chert and clays. Labile components such as feldspars. shell debris and faecal pellets were

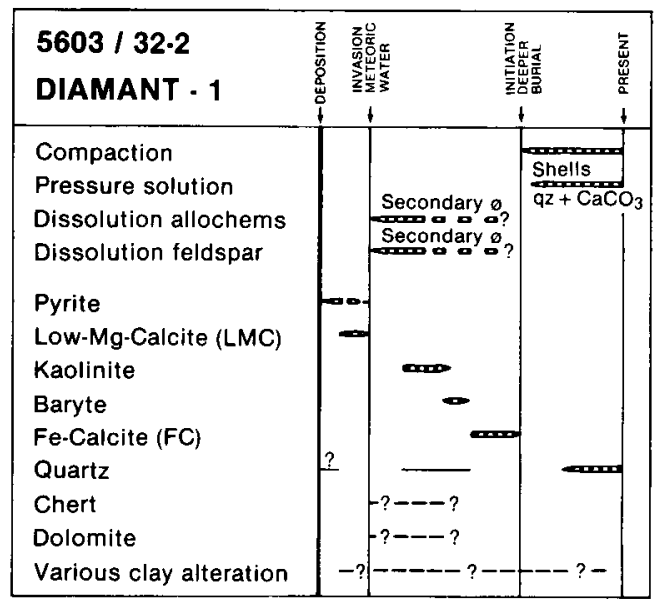

intensely dissolved. This sudden break in the line of diagenetic alterations set by step 1 indicates a dramatic shift in pore water composition from marine to meteoric. The $\delta^{18} \mathrm{O}$ composition of the Fe-calcite implies pore water ratios of $7-9 \%$ SMOW, which for a very shallow burial origin is in agreement with a meteoric regime. ${ }^{87} \mathrm{Sr} /{ }^{86} \mathrm{Sr}$ ratios indicate that the constituents needed for precipitation of $\mathrm{Fe}$ - calcite were derived from dissolution of the shell debris.

Step 3, burial: Compaction, pressure solution and overgrowth of quartz. At a certain stage the authigenic quartz stabilized the grain framework of the sand, thus preserving both high porosities and high permeabilities.

Potassium depletion by meteoric water invasion following deposition is thus indicated for the Diamant-1 well. Further, the sandstones are not illitized. Therefore, the alterations fit the model outlined above. However, the Heno Formation in the Diamant- 1 is buried to $3800 \mathrm{~m}$ only, and, therefore, this well does not effectively test the possibility of a significant delay of illite formation.

\section{References}

Andersen, P. R. (in prep.): The diagenesis of Upper Jurassic barrier island complex sands, Danish North Sea sector: An O, C and Sr stable isotope study. Geol. Surv. of Denmark Ser. A.

Bjørkum, P. A. \& Gjelsvik, N., 1988: An isochemical model for formation of authigenic kaolinite, K-feldspar and illite in sediments. Jour. Sed. Petrology 88, 506-511.

Bjørlykke, K., Aagaard, P., Dypvik, H., Hastings, D. S. \& Harper, A. S., 1986: Diagenesis and reservoir properties of Jurassic sandstones from the Haltenbanken area, offshore mid Norway. In: A. M. Spencer et al. (eds): Habitat of Hydrocarbons on the Norwegian Continental Shelf. Graham \& Trotman, London, 275-286.

Lønøy, A., Akselsen, J. \& Rønning, K., 1986: Diagenesis of a deeply buried sandstone reservoir: Hild Field, Northern North Sea. Clay Minerals 21, 497-511. 